\title{
Mechanical Behavior of Single Crystalline and Polycrystalline Silicon Carbides Evaluated by Vickers Indentation
}

\author{
Hiromoto KITAHARA, Yutaka NODA, Fuyuki YOSHIDA, Hideharu NAKASHIMA, \\ Nobuhiro SHINOHARA* and Hiroshi ABE \\ Department of Molecular and Material Sciences, Graduate School of Engineering Sciences, Kyushu University, \\ 6-1, Kasugakoen, Kasuga-shi, Fukuoka 816-8580 \\ *Research Center, Asahi Glass Co., Ltd., 1150, Hazawa-cho, Kanagawa-ku, Yokohama-shi, Kanagawa 221-8755
}

\author{
ビッカース圧子による単結晶及び焼結炭化ケイ素の機械的挙動の評価 \\ 北原弘基·野田 隆·吉田冬樹·中島英治·篠原伸弘*·阿部 弘 \\ 九州大学大学院総合理工学府物質理工学専攻，816-8580 春日市春日公園 6-1 \\ *旭硝子(株)中央研究所，221-8755 横浜市神奈川区羽沢町 1150
}

\begin{abstract}
Fracture toughness, fracture surface energy and crack initiation load of single crystal and polycrystalline SiC sintered with different additives were evaluated by Vickers indentation technique. Resistance to crack initiation and propagation in sintered $\mathrm{SiC}$ with $\mathrm{Al}_{2} \mathrm{O}_{3}$ additive was $>$ sintered $\mathrm{SiC}$ with $\mathrm{B}$ and $\mathrm{C}$ additives $>$ single crystals. The properties of single crystals depended on crystal orientation, while little difference of properties was observed between $4 \mathrm{H}$ and $6 \mathrm{H}$ structures. High fracture toughness and fracture surface energy of $\mathrm{Al}_{2} \mathrm{O}_{3}$ containing $\mathrm{SiC}$ resulted from crack deflection and branching at grain boundaries. Slightly higher fracture toughness and fracture surface energy of $\mathrm{SiC}$ sintered with $\mathrm{B}$ and $\mathrm{C}$ additives, in comparison with single crystals, was caused by crack deflection which was observed even when transgranular propagation occurred due to the different crystal orientation of cleavage planes in each grain. A microstructure favorable for high toughness involves a more severe local damage beneath the indentation.
\end{abstract}

[Received March 23, 2001; Accepted May 23, 2001]

Key-words : Single crystal SiC, Sintered SiC, Fracture toughness, Fracture surface energy, Microstructure

1. Introduction

Silicon carbide $(\mathrm{SiC})$ is one of the most important ceramic materials for advanced structural applications because of its excellent high-temperature mechanical properties and good corrosion and wear resistance. ${ }^{1)-3)}$ However, $\mathrm{SiC}$ is relatively brittle, and has low reliability as a material for structural applications. Further improvement in mechanical properties is required for this material with high potential.

Study of the mechanical properties of $\mathrm{SiC}$ has been conducted using sintered $\mathrm{SiC}$ with different sintering additives; $\mathrm{B}$ and $\mathrm{C}$ in solid-phase sintering and $\mathrm{Al}_{2} \mathrm{O}_{3}, \mathrm{Al}_{2} \mathrm{O}_{3}$ and $\mathrm{Y}_{2} \mathrm{O}_{3}$, in liquid-phase sintering. ${ }^{4)-6)}$ Microstructures of sintered materials depend on the additives and sintering conditions and affect mechanical properties, such as high temperature strength and fracture toughness.

Room temperature and high temperature mechanical properties of single crystal $\mathrm{SiC}$ have been studied by several authors, using relatively small specimens.7)-9) Results of these studies indicate that grain boundaries have strong influence on the mechanical properties, sometimes in favor and adverse in others, depending on required properties and environment where materials are used.

The purpose of this study is to investigate the mechanical behavior of single and sintered silicon carbides and to clarify the relationship between properties and microstructures; placing emphasis on characteristics of crystals and grain boundaries. For this purpose, Vickers indentation technique was applied to $4 \mathrm{H}$ and $6 \mathrm{H}$ type single crystal $\mathrm{SiC}$ and to two sintered polycrystalline $\mathrm{SiC}$ with different additives and different microstructures.

\section{Experimental procedures}

Two types of single crystals and two types of sintered silicon carbides were prepared. One of the single crystals is hexagonal $4 \mathrm{H}$ type, which has been grown via gas phase reaction for the sake of power device applications. ${ }^{10)}$ The yellow transparent $4 \mathrm{H}$ crystal has been cut and diamond polished to $10 \times 10 \times 10 \mathrm{~mm}$ with $(0001),\{1 \overline{100}\}$ and $\{11 \overline{2} 0\}$ surfaces. $6 \mathrm{H}$ type single crystals with hexagonal shape which reflects crystal orientation were grown in the central area of an Achison furnace during the manufacture of $\mathrm{SiC}$ abrasives. ${ }^{8)}$ Dark green transparent crystals with about $10 \mathrm{~mm}$ large hexagonal C-plane and $2-3 \mathrm{~mm}$ thickness were cut and diamond polished to desired crystal orientations. The crystal orientation of single crystals was identified by Laue X-ray back diffraction technique.

Procedure to make $\mathrm{SiC}$ with $\mathrm{Al}_{2} \mathrm{O}_{3}$ additive is basically the same as is shown in the reference. ${ }^{5)}$ In this study, the compact was sintered in an argon atmosphere $(0.1 \mathrm{MPa})$ at temperatures of $1960^{\circ} \mathrm{C}, 2 \mathrm{~h}$ (hereafter called Al-1960). SiC with boron and carbon additives (hereafter called BC) is a commercial products; the properties of which are shown in Table 1. All sintered specimens were cut to $3 \mathrm{~mm}$ in thickness and diamond polished for indentation test. Properties of each $\mathrm{SiC}$ and measurement techniques are summarized in Table 1.

Vickers diamond indentation experiment was carried out at room temperature $\left(20-25^{\circ} \mathrm{C}\right)$ with Akashi MVK-H1 hardness tester for the test load of $0.098 \mathrm{~N}$ to $1.96 \mathrm{~N}$ and Akashi AVK-C1 hardness tester for the test load of $2.94 \mathrm{~N}$ to 196 N. Microstructures and cracks introduced by indentation were characterized with TEM (JEOL; JEM-2000EX/ T), FE-SEM (JEOL; JSM-6340F) and an optical microscope. X-ray powder diffraction technique was applied to identify phases in sintered SiC.

\section{Results and discussion}

The crystal orientation of the surface of each single crys- 
Table 1. Properties of Single Crystal and Sintered Silicon Carbides

\begin{tabular}{|c|c|c|c|c|c|c|c|c|}
\hline Sample & $\begin{array}{l}\text { Specific } \\
\text { gravity }^{* 1}\end{array}$ & $\begin{array}{c}\text { Indented } \\
\text { plane }\end{array}$ & $\begin{array}{l}\text { Color } \\
\text { looked through } \\
\text { indented plane }\end{array}$ & $E / \mathrm{GPa}^{* 2}$ & $\begin{array}{l}\text { Vickers hardness } \\
\text { (Load applied at } \\
\text { measurement) }\end{array}$ & $\begin{array}{c}\text { Load ued for } K_{1 C} \\
\text { measurement }^{* 4} \\
/ \mathrm{N}\end{array}$ & $\begin{array}{c}K_{1 C} / \\
\mathrm{MPa} \cdot \mathrm{m}^{1 / 2}\end{array}$ & $\begin{array}{c}\gamma_{i} \prime \\
\mathrm{J} / \mathrm{m}^{2}\end{array}$ \\
\hline \multirow{3}{*}{$4 \mathrm{H}-\mathrm{SiC}$} & \multirow{3}{*}{3.19} & $(0001)$ & Yellow & 434 & $\begin{array}{c}2273 \pm 88 \\
(2.94 \mathrm{~N}) \\
\end{array}$ & 2.94 & $\begin{array}{l}2.3 \pm 0.29\langle 11 \overline{2} 0\rangle \\
2.2 \pm 0.36\langle 1 \overline{1} 00\rangle\end{array}$ & $\begin{array}{l}5.5 \pm 1.43\langle 11 \overline{2} 0\rangle \\
5.1 \pm 1.56\langle 1 \overline{1} 00\rangle\end{array}$ \\
\hline & & $\{1 \overline{1} 00\}$ & Blue & 484 & $\begin{array}{c}2406 \pm 89 \\
(2.94 \mathrm{~N}) \\
\end{array}$ & 2.94 & $\begin{array}{c}2.8 \pm 0.38\langle 11 \overline{2} 0\rangle \\
1.8 \pm 0.16[0001]\end{array}$ & $\begin{array}{l}9.0 \pm 2.59\langle 11 \overline{12} 0\rangle \\
3.8 \pm 0.63[0001]\end{array}$ \\
\hline & & $\{11 \overline{2} 0\}$ & Blue & 483 & $\begin{array}{c}2200 \pm 121 \\
(2.94 \mathrm{~N})\end{array}$ & 2.94 & $\begin{array}{c}\text { not } \\
\text { measurable }\end{array}$ & $\begin{array}{c}\text { not } \\
\text { measurable }\end{array}$ \\
\hline \multirow{3}{*}{$6 \mathrm{H}-\mathrm{SiC}$} & \multirow{3}{*}{3.23} & $(0001)$ & Dark green & $434^{* 3}$ & $\begin{array}{c}2250 \pm 200 \\
(2.94 \mathrm{~N})\end{array}$ & 2.94 & $\begin{array}{l}2.4 \pm 0.18\langle\overline{1} 120\rangle \\
2.3 \pm 0.23\langle 1 \overline{1} 00\rangle\end{array}$ & $\begin{array}{l}6.1 \pm 0.90\langle 11 \overline{2} 0\rangle \\
5.7 \pm 1.12\langle 1 \overline{1} 00\rangle\end{array}$ \\
\hline & & $\{1 \overline{1} 00\}$ & Dark green & $484^{* 3}$ & $\begin{array}{c}2199 \pm 81 \\
(2.94 \mathrm{~N})\end{array}$ & 2.94 & $\begin{array}{c}2.5 \pm 0.90\langle 11 \overline{2} 0\rangle \\
1.9 \pm 0.20[0001]\end{array}$ & $\begin{array}{l}8.1 \pm 0.68\langle 11 \overline{2} 0\rangle \\
4.2 \pm 0.90[0001]\end{array}$ \\
\hline & & {$[11 \overline{2} 0\}$} & Dark green & $483^{* 3}$ & $\begin{array}{c}2242 \pm 129 \\
(2.94 \mathrm{~N})\end{array}$ & 2.94 & $\begin{array}{c}\text { not } \\
\text { measurable }\end{array}$ & $\begin{array}{c}\text { not } \\
\text { measurable }\end{array}$ \\
\hline $\mathrm{BC}$ & 3.16 & & Black & 430 & $\begin{array}{c}2383 \pm 102 \\
(49 \mathrm{~N})\end{array}$ & 9.8 & $2.9 \pm 0.25$ & $9.5 \pm 1.70$ \\
\hline $\mathrm{Al}-1960$ & 3.22 & & Black & 450 & $\begin{array}{c}2049 \pm 117 \\
(49 N)\end{array}$ & 98 & $6.3 \pm 0.70$ & $44.5 \pm 9.6$ \\
\hline
\end{tabular}

*1 measured by Archimedes method

*2 Young's modulus measured by ultrasonic puls method. In the case of single crystals, $E$ is the value for the direction perpendicular to the indented plane.

$* 3$ the values of $4 \mathrm{H}$ was used

*4 with the applied load, the relation C/a> 2.5 is satisfied ; refer to JIS R 1607-1995

※ \pm refers to standard deviation

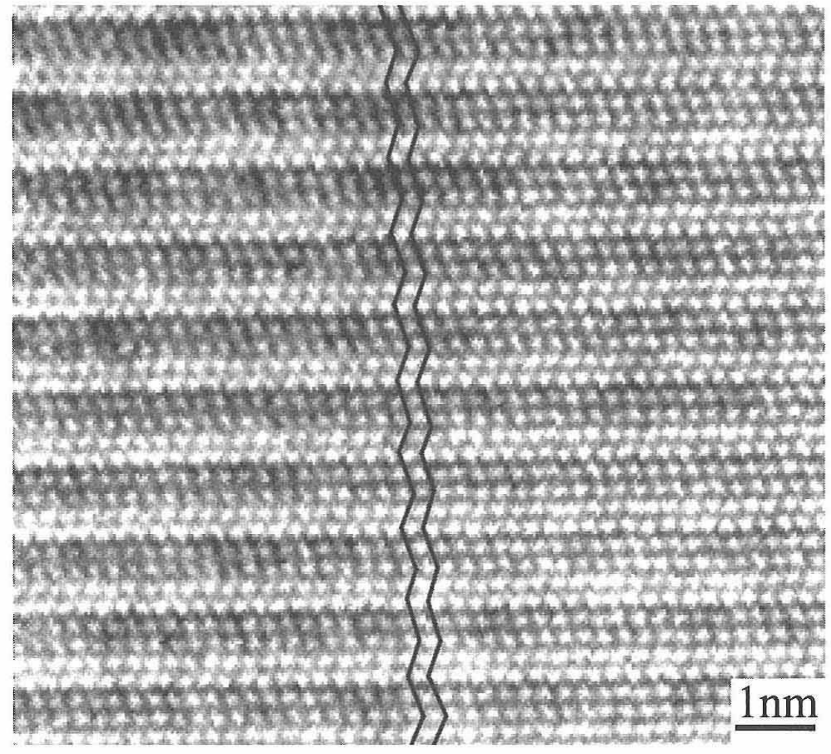

Fig. 1. HRTEM image of a grain in Al-1960.

tal of $4 \mathrm{H}$ and $6 \mathrm{H}$ were identified to be, (0001), \{1100\} and $\{11 \overline{2} 0\}$, respectively. Sintered $\mathrm{SiC}$ with $\mathrm{Al}_{2} \mathrm{O}_{3}$ additive mainly consisted of elongated interlocking grains of about $10 \mu \mathrm{m}$ in length and average aspect ratio of 3.5. X-ray powder diffraction pattern shows that $4 \mathrm{H}$ and $6 \mathrm{H}-\mathrm{SiC}$, small amount of $3 \mathrm{C}-\mathrm{SiC}$ and $\alpha-\mathrm{Al}_{2} \mathrm{O}_{3}$ are present in Al-1960. Sintered $\mathrm{BC} \mathrm{SiC}$ is consisted of $2-8 \mu \mathrm{m}$ equiaxial $6 \mathrm{H}$ polytype grains with small amount of 3C. Figure 1 shows a TEM microgragh of $4 \mathrm{H}$ structure in a grain of Al-1960. Grains in Al-1960 are mainly consisted of $4 \mathrm{H}$ structure but are accompanied with small amount of $3 \mathrm{C}$ with $4 \mathrm{H}(0001)$ and $3 \mathrm{C}$

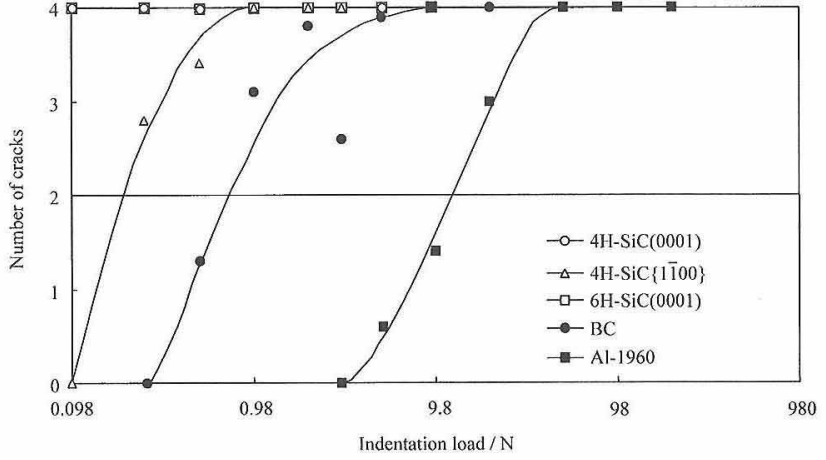

Fig. 2. Number of cracks formed at different indentation loads.

(111) stacking layers. The $4 \mathrm{H}(0001)$ crystal plane is in parallel with the long axis of the elongated grain. Similar structures of $6 \mathrm{H}$ and $3 \mathrm{C}$ stackings were also found in sintered $\mathrm{SiC}$ with $\mathrm{B}$ and $\mathrm{C}$ additives.

3.1 Load for crack initiation

When a Vickers indentation is made with a load which is larger than a critical value, radially oriented cracks at right angles arise from the four corners of the impression. ${ }^{11,12)} \mathrm{At}$ transition loads, one to three cracks are formed. Figure 2 shows the relationship between indentation load and the number of cracks formed in the surface of silicon carbides after $15 \mathrm{~s}$ of indentation. The number of cracks is the average of ten indentations. As for single crystals, indentation was made so that cracks can be formed to the directions $\langle 1 \overline{1} 00\rangle$ and $\langle 11 \overline{2} 0\rangle$ on (0001) surface, while $\langle 11 \overline{2} 0\rangle$ and $[0001]$ on $\{1 \overline{1} 00\}$ surface. When indentation was made on $\{11 \overline{2} 0\}$ surface, cracks were irregular in shape and the number of cracks could not be determined. At the load lower than $0.5 \mathrm{~N}$, cracks were so small that it was sometimes hard to decide whether there were cracks or not. Especially on 
$6 \mathrm{H}\{1 \overline{1} 00\}$, the number of cracks measured was not judged to be reliable; therefore plots for $6 \mathrm{H}\{1 \overline{1} 00\}$ were not given in Fig. 2. Photomicrographs of cracks in the surface of $6 \mathrm{H}$ single crystals are given in Fig. 3 . In both $4 \mathrm{H}$ and $6 \mathrm{H}$ single crystals, the shape of cracks was similar in the same crystal orientations.

Defining the crack initiation load as the load at which two cracks are formed, ${ }^{13)}$ the order of the resistance to crack initiation was determined to be, Al-1960; 9.8-19.6 N>BC; $0.5-1 \mathrm{~N}>4 \mathrm{H} \quad\{1 \overline{1} 00\} ; 0.1-0.25 \mathrm{~N}>4 \mathrm{H}(0001)=6 \mathrm{H}(0001)$; $\sim 0.1 \mathrm{~N}$, respectively. The results show that sintered $\mathrm{SiC}$ with $\mathrm{Al}_{2} \mathrm{O}_{3}$ additive has higher resistance; two orders of magnitude in load, to crack initiation compared with single crystals. $\mathrm{SiC}$ with $\mathrm{B}$ and $\mathrm{C}$ additives is less resistance to crack initiation compared with sintered $\mathrm{SiC}$ with $\mathrm{Al}_{2} \mathrm{O}_{3}$ additive. In single crystals, when indentations were made in the crystal orientations other than the four crystal orientations described above, the crack initiation load was always smaller than that of sintered $\mathrm{SiC}$, and in many cases, the shape of cracks was irregular.

3.2 Fracture toughness and fracture surface energy

Fracture toughness was calculated based on the equation of IF(Indentation Fracture) method in JIS R1607-1995. The thickness of $6 \mathrm{H}$ specimens was about $2 \mathrm{~mm}$ and was thinner than $3 \mathrm{~mm}$ that is required thickness described in the JIS. The results, however, show that the crack length " $2 \mathrm{C}$ " and indentation diagonal " $2 \mathrm{a}$ " coincide well for $4 \mathrm{H}$ and $6 \mathrm{H} \mathrm{SiC}$ when indentation was made in the same crystal orientations, indicating that the effect of thickness was insignificant, if ever. The fracture toughness was calculated at the loads when the requirement of $\mathrm{C} / \mathrm{a}>2.5$ was satisfied. The loads used for calculation were $2.94 \mathrm{~N}$ for all single crystals, $9.8 \mathrm{~N}$ for sintered $\mathrm{BC}$ and $980 \mathrm{~N}$ for $\mathrm{Al}-1960$, respectively.

With regard to calculation for single crystals, the fracture toughness may be an apparent value, because the related properties, such as Young's modulus $E$, differ from one direction to the others. The measured fracture toughness is shown in Table 1 . The values are the average of ten indentations. The order of fracture toughness is Al-1960 (6.3 $\left.\mathrm{MPa} \cdot \mathrm{m}^{1 / 2}\right)>\mathrm{BC}\left(2.9 \mathrm{MPa} \cdot \mathrm{m}^{1 / 2}\right)>$ single $\operatorname{crystal}(1.8-2.8$ $\mathrm{MPa} \cdot \mathrm{m}^{1 / 2}$, depending on crystal orientations). The fracture toughness values of $4 \mathrm{H}$ and $6 \mathrm{H}$ single crystals are about the same for the same crystal orientations.

Fracture surface energy $\gamma_{i}$ was calculated using the equation $\gamma_{\mathrm{i}}=K_{\mathrm{IC}}{ }^{2} /(2 E)$, and is given in Table 1 . The equation $\gamma_{\mathrm{i}}$ $=K_{\mathrm{IC}}{ }^{2}\left(1-v^{2}\right) /(2 E)$, where $v$ is Poison's ratio, should be used in a plain strain conditions. ${ }^{14)}$ However, $v^{2}$ is about 0.02 omitted for the simplicity of calculation. The order of fracture surface energy is A1-1960 $\left(44.5 \mathrm{~J} / \mathrm{m}^{2}\right)>\mathrm{BC}(9.5 \mathrm{~J} /$ $\left.\mathrm{m}^{2}\right)>$ single crystals $\left(3.8-9.0 \mathrm{~J} / \mathrm{m}^{2}\right)$. Similar to the results of fracture toughness, the fracture surface energies of $4 \mathrm{H}$ and $6 \mathrm{H}$ single crystals are about the same for the same crystal orientations. In order to assist understanding the actual features of crack propagation, it is preferable to convert the direction of indentation diagonals to the orientation of cleaved planes. The order of fracture surface energy is summarized; from large $\gamma_{\mathrm{i}}$ to small $\gamma_{\mathrm{i}}$, as follows,

$\begin{array}{cccc}\text { Indented } & \begin{array}{c}\text { Direction of } \\ \text { plane }\end{array} & \begin{array}{c}\text { diagonals } \\ \text { Cleaved }\end{array} & \gamma_{\mathrm{i}} / \mathrm{J} / \mathrm{m}^{2} \\ \{1 \overline{1} 00\} & \langle 11 \overline{2} 0\rangle & \text { plane } & \\ (0001) & \langle 1 \overline{1} 00\rangle \text { or }\langle 11 \overline{2} 0\rangle & \{11 \overline{2} 0\} \text { or }\{1 \overline{1} 00\} & 5.1-9.0 \\ \{1 \overline{1} 00\} & {[0001]} & \{11 \overline{2} 0\} & 3.8-4.2\end{array}$

It is to be noticed that both $K_{\mathrm{IC}}$ and $\gamma_{\mathrm{i}}$ are, respectively, about the same for $\{11 \overline{2} 0\}$ and $\{1 \overline{1} 00\}$ cleavages when indentation was made on (0001), although the two crystallographic orientations are not equivalent in a hexagonal crystal structure. The relation between crystal orientations and fracture surface energies has a similar tendency to that reported for $\alpha-\mathrm{Al}_{2} \mathrm{O}_{3}$, which has a rhombohedral-hexagonal crystal structure. ${ }^{15), 16)}$ In terms of the fundamental mechanical properties of single crystal silicon carbides, the fracture surface energy $\gamma_{\mathrm{i}}$ is approximately the same as that of a commercial soda-lime silica glass; 13 ) $5.2 \mathrm{~J} / \mathrm{m}^{2}$. While, even a single crystal $\mathrm{SiC}$ has the fracture toughness of about $2 \mathrm{MPa}$. $\mathrm{m}^{1 / 2}$, which is much higher than that of glass; $0.75 \mathrm{MPa}$. $\mathrm{m}^{1 / 2}$. The higher $K_{\mathrm{IC}}$ of single crystal $\mathrm{SiC}$ is due to the higher Young's modulus which is in the order of $450 \mathrm{GPa}$ as opposed to the low Young's modulus of glass; ${ }^{13)} 72 \mathrm{GPa}$.

\subsection{Fracture characteristics}

Radially oriented cracks are formed due to residual stresses generated by a radially expanded plastic zone and a surrounding elastic field which were caused by Vickers indentation. ${ }^{3), 12), 15)}$ In single crystals, when a tensile stress is applied perpendicular to the cleavage plane, a crack tends to propagate straight along the cleavage plane hence the resistance to crack initiation and propagation can be minimal. The low crack initiation load, fracture toughness and the fracture surface energy of single crystal SiC come from this geometrical factor. The other factor to enhance a crack initiation and propagation in single crystals, and in $\mathrm{BC}$, is considered to be the well-defined shape of the impression, indicating a large stress concentration at the corner of Vickers impression. Figure 3 compares the shapes of the corners of impression of $6 \mathrm{H}$-single crystal and sintered Al-1960. In a single crystal, the shape of the corner is well defined but in a sintered specimen with $\mathrm{Al}_{2} \mathrm{O}_{3}$ additive, the shape of the corner is very fuzzy via grain boundary crack-

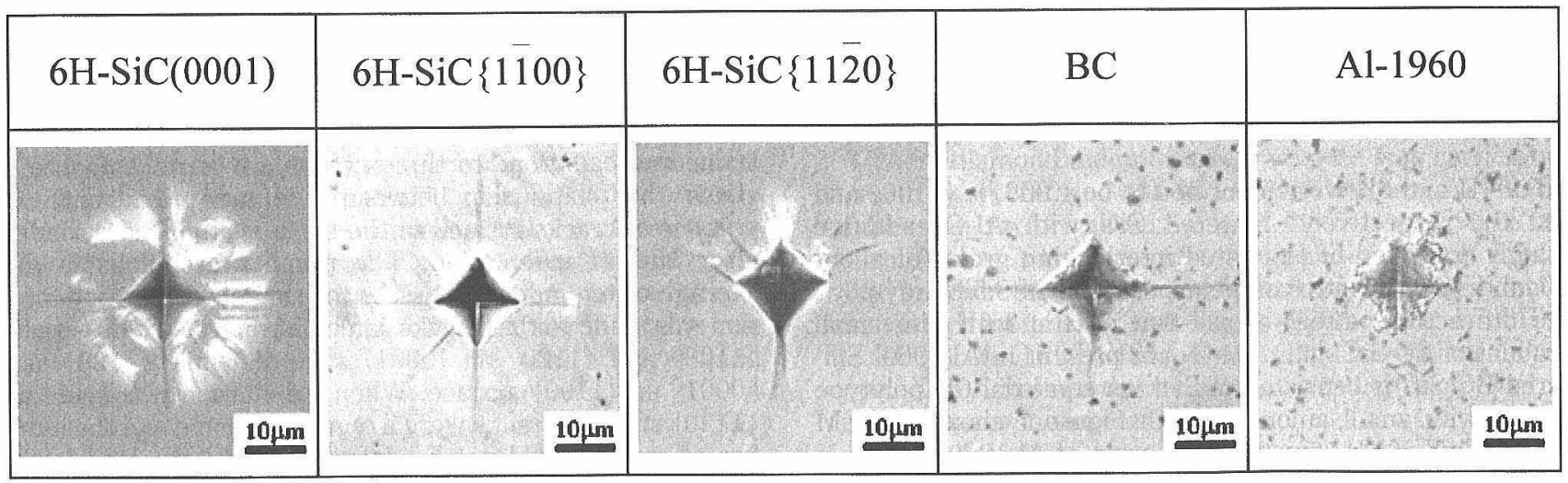

Fig. 3. Optical micrographs of cracks and impressions in single crystal and sintered SiC indented at $2.94 \mathrm{~N}$. 
ing. In the latter, the corner is rough and zig-zag shaped. Precisely speaking, the application of IF method may not be made when chipping is observed at the edges or corners of impression. ${ }^{14)}$ However, when IF method is applied to ordinary ceramics with relatively high $K_{\mathrm{IC}}$, a similar phenomenon is often observed. With regard to the application of different test methods to measure $K_{\text {IC }}$ of high toughness ceramics, the physical meaning of the value obtained in each test method has to be taken into consideration. ${ }^{17)}$

The high fracture toughness and the high crack initiation load of $\mathrm{Al}_{2} \mathrm{O}_{3}$ containing sintered $\mathrm{SiC}$ result from elongated grains with high aspect ratio, which causes crack deflection and bridging at grain boundaries as is seen in Fig. 4.The crack in $\mathrm{BC}$ tends to propagate transgranurally. The fracture toughness of $\mathrm{Al}_{2} \mathrm{O}_{3}$ containing sintered $\mathrm{SiC}$ is two times larger than that of $\mathrm{B}$ and $\mathrm{C}$ containing $\mathrm{SiC}$ and as large as the toughness of sintered $\mathrm{Si}_{3} \mathrm{~N}_{4}{ }^{18}$ ) Based on the fact that the deflection of cracks at grain boundaries are frequently observed in Al-1960 and that the fracture surface energy of single crystals is about $5 \mathrm{~J} / \mathrm{m}^{2}$, it is considered that the high $\gamma_{\mathrm{i}}$ of $\mathrm{Al}_{2} \mathrm{O}_{3}$ containing $\mathrm{SiC} ; 45 \mathrm{~J} / \mathrm{m}^{2}$, actually results from the small fracture energy at grain boundaries. The fracture sur-

(a)

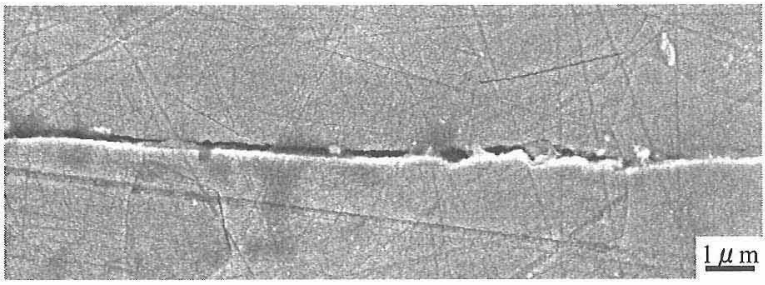

(b)

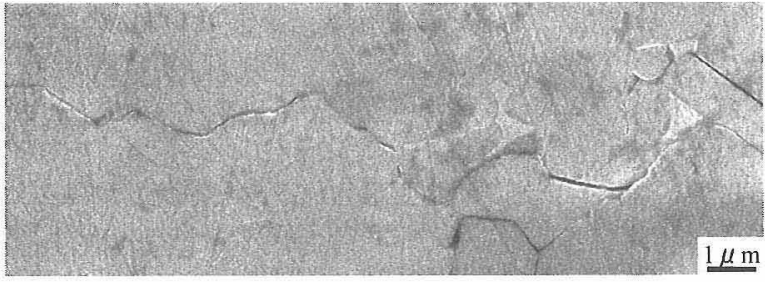

Fig. 4. SEM images of crack propagation behavior of (a) $\mathrm{BC}$ and (b) Al-1960 after etched in a solution of $\mathrm{H}_{2} \mathrm{O}(100 \mathrm{ml}), \mathrm{K}_{3} \mathrm{Fe}(\mathrm{CN})_{6}$ $(10 \mathrm{~g})$ and $\mathrm{NaOH}(10 \mathrm{~g})$ at $373 \mathrm{k}$ for $780 \mathrm{~s}$.

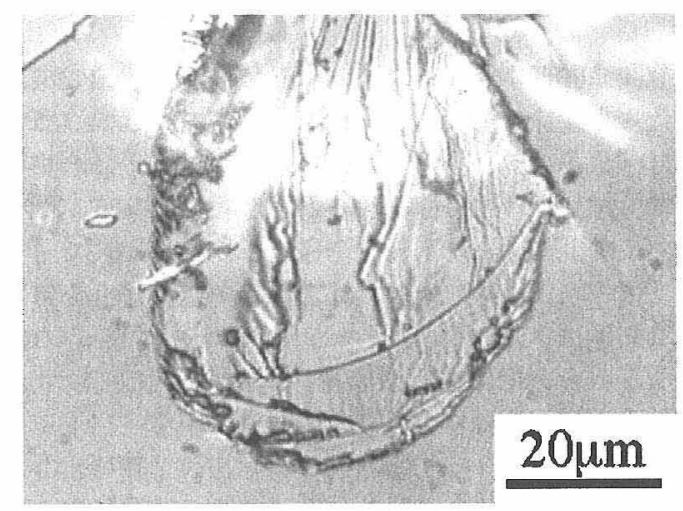

(a) $6 \mathrm{H}-\mathrm{SiC}(0001)$ face energy at grain boundaries of $\mathrm{Al}_{2} \mathrm{O}_{3}$ containing $\mathrm{SiC}$ is, thus, assumed to be smaller than the single crystal value; approximately $5 \mathrm{~J} / \mathrm{m}^{2}$.

At low loads, the local damage beneath the impression is more critical in $\mathrm{Al}_{2} \mathrm{O}_{3}$ containing sintered $\mathrm{SiC}$ than that of in either single crystals or $\mathrm{B}$ and $\mathrm{C}$ containing SiC. A sharp pyramid shape is impressed in the latter, while, cracking at grain boundaries is observed at the edges, corners and beneath the indentation of $\mathrm{Al}_{2} \mathrm{O}_{3}$ containing $\mathrm{SiC}$ as is shown in Fig. 3. Similar complicated relationship between damage and microstructure is reported for the indentation study of ceramics with sphere. ${ }^{19)}$ Indentation with a sphere causes a sharp Hertz crack for sintered alumina with fine grains, while no Hertz cracks but interior damages were introduced to alumina with coarse grains.

In sintered $\mathrm{SiC}$ with $\mathrm{B}$ and $\mathrm{C}$ additives, grain boundaries have a relatively strong bond ${ }^{4)}$ and a crack tends to propagate transgranulary, which results in relatively low fracture toughness. The slightly higher resistance of B and $\mathrm{C}$ containing $\mathrm{SiC}$ to crack initiation and propagation, in comparison with single crystals, is due to the crack deflection, which is observed even in a transgranular fracture. Figure 5 compares the surfaces of conchoidal fracture, which were formed when an excessive load is applied to (0001) plane of $6 \mathrm{H}$-single crystal and $\mathrm{B}$ and $\mathrm{C}$ containing sintered $\mathrm{SiC}$. In a single crystal, a relatively smooth fracture surface is observed, while in the latter, the crack is clearly deflected; the crack propagates through planes of less resistant crystal orientations, hence causing a crack deflection. The summary of the fracture toughness and fracture surface energy of single crystal and sintered $\mathrm{SiC}$ is shown in Fig. 6.

\section{Conclusions}

The fracture toughness, fracture surface energy and the crack initiation load of single crystal and sintered $\mathrm{SiC}$ with different additives and different microstructures were evaluated by Vickers indentation technique. The results were summarized as follows:

(1) Resistance to crack initiation and propagation was in the order of, sintered $\mathrm{SiC}$ with $\mathrm{Al}_{2} \mathrm{O}_{3}$ additive $>$ sintered $\mathrm{SiC}$ with $\mathrm{B}$ and $\mathrm{C}$ additives $>$ single crystals.

(2) The properties of single crystals depended on the crystal orientation, while little difference of properties was observed between $4 \mathrm{H}$ and $6 \mathrm{H} \mathrm{SiC}$.

(3) High fracture toughness and fracture surface energy of $\mathrm{Al}_{2} \mathrm{O}_{3}$ containing $\mathrm{SiC}$ resulted from crack deflection and branching at grain boundaries.

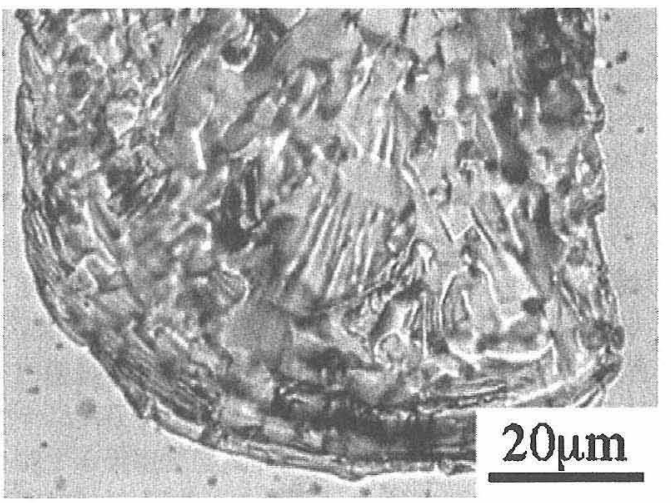

(b) $\mathrm{BC}$

Fig. 5. Optical micrographs of choncoidal fracture surfaces of (a) $6 \mathrm{H}$ single crystal indented at $1.96 \mathrm{~N}$ and (b) sintered $\mathrm{SiC}$ with $\mathrm{B}$ and $\mathrm{C}$ additives indented at $98 \mathrm{~N}$. 


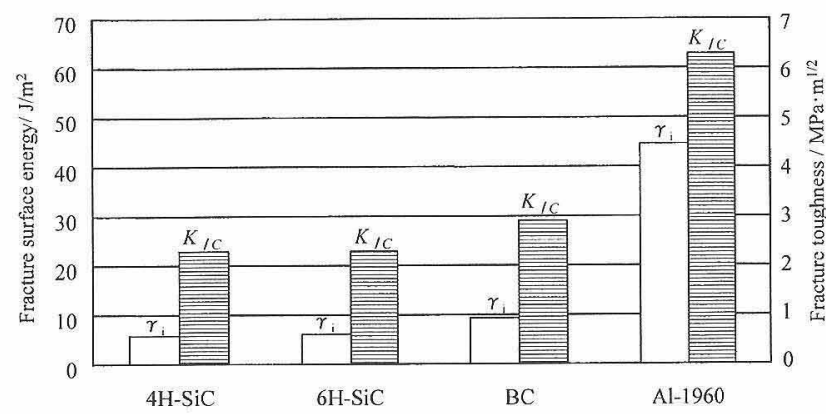

Fig. 6. Fracture surface energy and fracture toughness of silicon carbides. Data for each single crystal are the average of different crystal orientations indicated in Table 1.

(4) Slightly higher fracture toughness and fracture surface energy of sintered $\mathrm{SiC}$ with $\mathrm{B}$ and $\mathrm{C}$ additives, in comparison with single crystals, was caused by crack deflection which was observed even in a transgranular fracture due to the different crystal orientation of cleavage planes of each grain.

(5) The microstructure which is favorable for higher fracture toughness tends to cause severer local damages beneath the indentation impression.

Acknowledgement This work has been supported by Grant-in Aid for Scientific Research (No. 10450244) from the Ministry of Education, Science, Sports and Culture, Japan.

\section{References}

1) Yoshida, K., Imai, M. and Yano, T., J. Ceram. Soc. Japan, $108,224-29(2000)$
2) Whalen, T. J., Ceram. Eng. Sci. Proc., 7, 1135-43 (1986).

3) Sakai, M. and Bradt, R. C., Int. Mat. Reviews, 38, 53-78 (1993).

4) Chandan, H. C., Hermansson, L., Abe, H. and Bradt, R. C., Ceramics International, 9, 114-18 (1983).

5) Shinozaki, S. S., Hangas, H., Carduner, K. R., Rokosz, M. J., Sizuki, K. and Shinohara, N., J. Mater. Res. Soc., 8, 1635-43 (1993).

6) Nagano, T., Kaneko, K., Zhan, G. D. and Mitomo, M., J. Am. Ceram. Soc., 83, 2497-502 (2000).

7) Sasaki, G., Hiraga, K., Hirabayashi, M., Niihara, K. and Hirai, T., J. Ceram. Soc. Japan (Yogyo-Kyokai-Shi), 94, 779-83 (1986) [in Japanese].

8) Maeda, K., J. Ceram. Soc. Japan (Yogyo-Kyokai-Shi), 94, 784-89 (1986) [in Japanese].

9) Kawahara, K., Ph. D. Thesis, Kyushu University, 35-62 (1998) [in Japanese].

10) Arai, K., Ceramics Japan, 35, 831-35 (2000) [in Japanese].

11) Lawn, B. R., Evans, A. G. and Marshall, D. B., J. Am. Ceram. Soc., 63, 574-81 (1980).

12) Abe, H., Ikeda, K., Nakashima, H., Yoshida, F. and Koga, K., J. Ceram. Soc. Japan, 108, 416-19 (2000).

13) Sehgal, J. and Ito, E., J. Am. Ceram. Soc., 81, 2485-88 (1998).

14) Sakai, M., "Advanced Ceramics," Ed. by Matsuo, Y., Abe, H. and Matsuo, Y., Ohm Press (1991) pp. 38-85 [in Japanese].

15) Tatami, J., Yasuda, K., Matsuo, Y. and Kimura, S., "Materials Science and Engineering Serving Society," Ed. by Sōmiya, S., Chang, R. P. H. and Roy, R., Elsevier Science B. V. (1998) pp. 69-72.

16) Bradt, R. C., "Proceedings of George R. Irwin Symposium," Ed. by Chan, K. S., Publication of TMS (1997) pp. 355-65.

17) Yoshizawa, Y., Toriyama, M. and Kanzaki, S., J. Ceram. Soc. Japan, 108, 558-64 (2000) [in Japanese].

18) Kitayama, M., Hirao, K., Toriyama, M. and Kanzaki, S., J. Ceram. Soc. Japan, 108, 646- 49 (2000).

19) Lawn, B. R., J. Am. Ceram. Soc., 81, 1977-94 (1998). 